\title{
SB 983
}

.M6 A5

1914

Copy 1

\section{MICHIGAN LAWS}

FOR THE PROTECTION

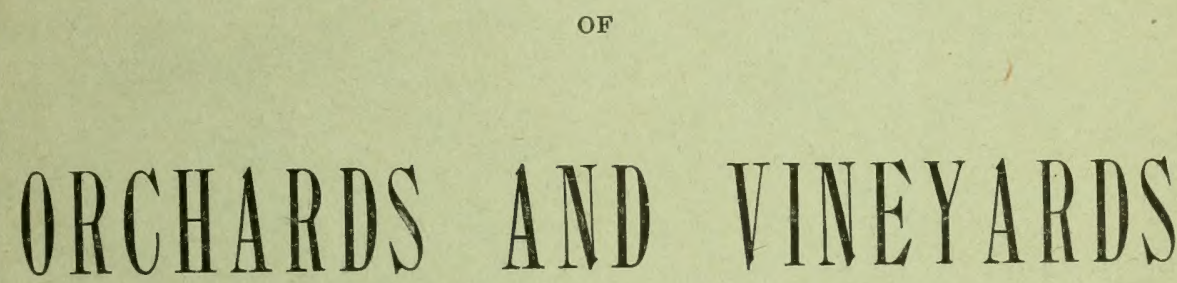

COMPILED UNDER THE SUPERVISION OF

FREDERICK C. MARTINDALE

SECRETARY OF STATE

\section{4}





\section{MICHIGAN LAWS}

\section{FOR THE PROTECTION}

OF

\section{ORCHARDS}

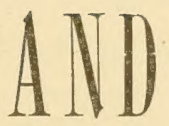

VIIEYARIS

COMPILED UNDER THE SUPERVISION OF

FREDERICK C. MARTINDALE

SECRETARY OF STATE

1914 


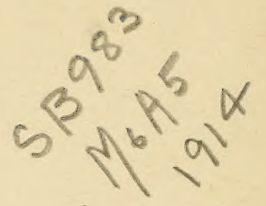

$$
\begin{aligned}
& \text { D. of } D_{\text {. }} \\
& \text { JAN i2 }
\end{aligned}
$$




\section{PROTECTION OF ORCHARDS AND VINEYARDS.}

An Act to prevent the importation from other states and the spread within this state, of dangerous insects and dangerously contagious diseases affecting trees, shrubs, vines, plants and fruits, and to repeal all acts or part [parts] of acts that contravene the provisions of this act.

$$
\text { [Act 91, P. A. 1905.] }
$$

\section{The People of the State of Michigan enact:}

Section 1. It shall be unlawful for any person or persons, Infected trees firm or corporation, knowingly, to keep upon their premises, unlawful to or upon premises under their control or charge, any trees or fruit infected with the diseases known as peach yellows, rosette, $\mathrm{Or}^{\sim}$ little peach, or any part of a tree infected with the diseases known as black knot or pear blight, or any tree, shrub, plant or vine infected with any other dangerously contagious disease, or infested with the San Jose scale, cankerworm or any other dangerously noxious insect pest. It shal! Unlawful to also be unlawful for any person or persons, firm or corpora sell infected tion knowingly, to sell or offer for sale, or to give away, any tree, shrub, plant, or vine, infected or infested with any dangerously infectious disease or noxious insect, or any fruit infected with peach yellows.

SEc. 2. The state board of agriculture shall, upon the state inpassage of this act, appoint some competent person to be orchards, who known as state inspector of orchards and nurseries, who shall to appoint. hold office for two years, and whose duties shall be as hereinafter prescribed. He shall have power to appoint such num- Deputies. ber of deputy inspectors as may be necessary, subject to the approval of the state board of agriculture. Said deputy inspectors shall act under the orders of, and shall perform such duties as may be directed by the state inspector of orchards and nurseries. The salary, or per diem, of the state salary or and deputy inspectors shall be fixed by the state board of per diem. agriculture.

SEC. 3. Any person or persons, firm or corporation, grow-Growers or ing or offering for sale, in this state, any trees, shrubs, vines dealers to or plants, commonly kuown as nursery stock, shall, on or inspected. before the first day of August in each year, apply to the Michigan state board of agriculture for the inspection of said stock under the provisions of this act and for a license for its 
Amount of license and bond.

No stock to be shipped with-
out certificate.

Must furnish list of purchasers.

Proviso.

Further proviso.

Dealers must secure license and certificate.

When license to be issued.

State inspector, duty of.

When certificate of inspec tion given.

Certificate may be revoked. sale. A license fee of five dollars shall be paid, and a bond for one thousand dollars, with sureties satisfactory to said board, and conditioned upon the compliance with the require. ments of this act, shall be filed. No nursery stock shall be shipped $\mathrm{rr}^{*}$ delivered until it has been examined by the state inspector of orchards and nurseries, or a deputy inspector and has received a certificate as hereinafter provided. All growers or dealers in nursery stock, shall, upon demand file with the state board of agriculture a list of the persons to whom they have sold or delivered any nursery stock, giving the species, which list shall be for the sole use of the state inspector of orchards and nurseries and his deputies: Provided, That the provisions of this section shall not apply to persons engaged in fruit growing, who are not nurserymen, but desire to sell or exchange surplus small fruit plants of their own growing: Provided further, That the provisions of this section shall not apply to farmers or other persons who may sell shade trees from their own wood lots.

SEc. 4. No person or persons, firm or corporation, residents of another state, territory, province or country, shall engage or continue in the business of selling, or taking orders within this state for the sale of any trees, plants, shrubs or vines, commonly known as nursery stock, without first obtaining from the state board of agriculture a license as provided for in section three of this act, and filing a certificate of inspection from a state or government officer, or some person designated by the Michigan state board of agriculture.

SEc. 5. The state board of agriculture, shall, upon the receipt of the required fee and a satisfactory bond and certificate of inspection, issue a license to each applicant, whether a resident of this state, or of another state, province, $\mathrm{or}^{\circ}$ country, permitting the sale of nursery stock by the holder, or by his accredited agents, for the period ending the thirty-first of July following the date upon which said license goes into effect.

SEc. 6. It shall be the duty of the state inspector of orchards and nurseries to examine all,nurseries in the state, at least once each year, for the presence of San Jose scale and other dangerously injurious insects and diseases. If found to be apparently free from such dangerous insects and diseases, a certificate to that effect shall be given the owner, upon the payment of an inspection fee sufficient to defray the per diem of the inspector. Said certificate shall be void on the thirty-first day of July following. In case any dangerous insect or infectious disease is found upon any nursery stock, the inspector shall order and enforce such treatment as may be deemed sufficient to exterminate such insects or diseases before granting a certificate. If a subsequent examination shall show the stock to be infected, or infested, the certificate may be revoked. 
SEc. 7. Whenever a nurseryman or other person shall ship Nurserymen or deliver within this state, except for scientific purposes, any to place copy trees, shrubs, plants or vines, commonly known as nursery on packages, stock, he shall place upon each car, box, bale or other package. a copy of a certificate of inspection, the original of which is signed by said inspector. Failure to do this, or the illegal when liable use of said certificate by changing, defacing, or placing it upon uninspected stock, or using the same after it has expired, or been revoked, shall render the shipper or owner liable to the penalties prescribed for a violation of this act. Dealers in How dealers nursery stock purchased from other firms may, upon filing may receive with the state inspector of orchards and nurseries duplicate $\begin{gathered}\text { stock pur- } \\ \text { chased. }\end{gathered}$ copies of the certificates of inspection issued upon the stock grown by said firms, and on the payment of a fee of one dollar, receive a certificate showing that the stock has been inspected. Said certificate may be used for the shipment of nursery stock that has come to them accompanied by a certificate of inspection, but for no other. Nurserymen may ship under their own certificate of inspection any stock that has come to them later than the first day of the previous August accompanied by a certificate of inspection, and, if from another state, territory, province or country, by a certificate of fumigation as required by this act.

SEC. 8. If any nursery stock of species subject to the attack when stock to of the San Jose scale, has been grown within one-half mile of where the San Jose scale exists, or has been known to exist within two years, it shall, before it is shipped or delivered, be fumigated with hydrocyanic acid gas of the strength commonly used for such purpose, for not less than thirty minutes. All trees, plants, shrubs and vines, of species subject to the attack of the San Jose scale, shipped into this state from another state, territory, province or country, must be fumigated with hydrocyanic acid gas in the usual manner, and each car, box or bale, in which said nursery stock is Certificate atshipped, shall have upon it a certificate signed by the shipper or car, what stating that such fumigation has been given in addition to the to state. usual certificate of inspection.

SEC. 9. The owner of any nursery trees, vines, shrubs or Duty of owner plants, upon receiving notice from the state inspector of upon receipt orchards and nurseries, that any, or all of them, are infected trees are inor infested with dangerous insects or diseases, shall, within the time specified in such notice, take such steps as will fully comply with the orders of the state inspector of orchards and nurseries and he shall not ship or deliver any such trees, vines, shrubs or plants, until after they have received such treatment, and until they have been re-examined and a certificate of inspection has been granted.

SEc. 10. Whenever it shall happen that the state inspector Inspector to of orchards and nurseries shall give the notice heretofore make comrequired to the owner of nursery stock, for the destruction of seize stock. 
How seized stock disposed of.

Stock from other states, to have label and certificat attached.

Railway companies, etc. to report violation.

Misdemeanor what deemed.

When inspector may seize stock.

Notice to shippers.

How stock disposed of.

Inspector to notify owner of infected orchards. the insects or diseases mentioned, and said owner shall fail or neglect to take the measures necessary for the destruction thereof, within the time mentioned in the notice given him, the state inspector of orchards and nurseries shall enter complaint against said owner and may seize and take possession of said-infected or infested nursery stock. Such seizure may be made without a warrant. Said infected or infested nursery stock shall be disposed of in such manner as may be directed by the court before whom the offense is tried, or by any court of competent jurisdiction.

Sec. 11. Whenever any trees, shrubs, plants or vines, commonly known as nursery stock are shipped into this state from another state, territory, province or country, every package thereof shall be plainly labeled on the outside with the names of the consignor and consignee, and the character of the contents, and certificates shall be attached to each package showing that the contents have been inspected by a state and government officer, and that they have been fumigated in the usual manner with hydrocyanic acid gas. If any trees, shrubs, vines or plants, commonly known as nursery stock, are shipped into this state without such certificates being plainly fixed on the outside of the package, box or car containing the same, the fact must be reported within twenty-four hours to the Michigan state board of agriculture, or its regularly appointed inspector, by the railway, express or steamboat company, or the person or persons carrying the same; and any agent of a railway, express or steamboat company, or any other person or persons, who shall fail to comply with the provisions of this section, shall be deemed guilty of a misdemeanor. The state inspector of orchards and nurseries shall have authority, when he has reason to believe that nursery stock, that has been shipped into the state, or shipped by some nursery in the state, is infested or infected with dangerous insects and diseases, to examine the same and, if found to be infected by any dangerously contagious disease, or infested with dangerous insects, such stock may be seized without a warrant as a public nuisance. The shippers shall be notified of the seizure, and orders shall be given him to either destroy the stock or to give it effectual treatment. If this is not done within five days, complaint shall be made to some court having competent jurisdiction and said infected or infested stock shall be disposed of in such manner as may be directed by said court.

SEc. 12. It shall be the duty of the state inspector of orchards and nurseries, whenever it shall come to his knowledge that San Jose scale, canker worm, peach yellows, rosette, little peach, black knot, or pear blight, or any other noxious insects or dangerously infectious diseases exist, or are supposed to exist, in any orchard, or upon any trees, shrubs, vines, plants or fruits in this state, to investigate the case and 
if such dangerous insects or diseases are found, he shall notify the owner, or his agent, in writing. The notice shall consist Notice, what of a simple statement of the facts as found to exist, with an to state. order to uproot and destroy in such manner as may be indicated, all trees infected with yellows, little peach, or rosette, or to cut off and burn the portions infected with black knot and pear blight, or if attacked by San Jose scale or canker worm, to effectually spray the trees, or to use such remedies as may be prescribed for other dangerous insects and diseases within five days, or such time from the date of the service of the notice as may be designated: Provided also, That no Proviso as to such spraying shall be done while said fruit trees or vines are spraying, and in blossom, except in case of canker worm. In the case of fruit. fruit infected with yellows, the notice shall require its immediate destruction. Failure to comply with the requirements when owner of said notice shall render the owner or agent liable to the subject to penalties prescribed for the violation of this act.

SEC. 13. In any township, village or city in this state in Duty of townwhich the insects known as the San Jose scale, and canker ship, village worm, or the diseases known as peach vellows, rosette, little officers in worm, or the diseases known as peach yellows, rosette, little officers in peach, black knot and pear blight, or any other destructive tricts. insects or dangerously infectious diseases exist, or in which there is good reason to believe they exist, or danger may be apprehended of their introduction, it shall be the duty of the township board, or the village, or city council, as soon as such information becomes known to such board or council, or any member thereof to appoint three competent freeholders of To appoint said township, village or city, to be known as fruit and orchard inspectors, who shall hold office during the pleasure of said board or council: Provided, That inspectors already Proviso. appointed and in office under similar and previous acts shall continue in said office under this act until the expiration of the term for which they were appointed.

SEc. 14. It shall be the duty of said inspectors, within ten Inspectors, days after appointment, as aforesaid, to file their acceptance duty of. of the same with the clerk of said township, village or city, and said clerk shall be ex officio clerk of said board of fruit and orchard inspectors, and he shall keep a record of the Clerk to keep proceedings of said board in a book to be provided for the record of propurpose and shall file and preserve all papers pertaining to the duties and actions of said inspectors, or either of them, which shall be a part of the records of said township, village or city.

SEC. 15. It shall be the duty of the township, village or when incity inspectors, or any one of them, whenever it comes to their spectors to exnotice that any of the dangerously injurious insects or diseases, mentioned in section thirteen of this act, exist, or are supposed to exist, within the limits of their township, village. or city, to proceed without delay to examine the trees, shrubs, rines, plants or fruits, supposed to be infested $\mathrm{or}^{\circ}$ infected, 
Mark placed on infected trees.

How owner may appeal from opinion of inspector.

Duty of inspectors upon appeal.

When owner may appeal to state inspector

Inspectors may obtain advice from state inspector.

When owner to pay expense of appeal.

How orders of inspectors made effective.

Expense, levied as special tax.

State inspector, etc., may enter any premises. and, if destructive insects or a dangerously infectious disease is found to exist, a distinguishing mark shall be placed upon the trees, shrubs, vines or plants, and a written notice shall be served upon the owner, or his agent. This notice shall be as provided for in section twelve of this act. In case the owner refuses to accept the opinion of a single inspector, regarding the nature of an insect or disease, or the remedy that shall be employed, he may, within two days, appeal to the other inspectors in the township, village or city, by serving a written notice of such appeal upon each of them. Upon receipt of such notice of appeal, it shall be the duty of each and every inspector, if he has not already done so, to examine the trees, shrubs, plants or vines, supposed to be infested or infected, and if all or a majority of said inspectors agree that a dangerous insect or disease is present, they shall serve notice upon the owner or his agent as above. If the decision of the full board of inspectors is still unsatisfactory to the person in charge, he may, within twenty-four hours, make an appeal to the state inspector of orchards and nurseries, who shall at once investigate the matter and order the proper treatment, and his opinion and orders shall be final. If the members of a township, village or city board of fruit and tree inspectors are unable to agree, or are in doubt, regarding the nature of an insect or disease, or the treatment that should be given, they may call upon the state inspector of orchards and nurseries for information and advice. In cases where an owner appeals to the full board of township, village or city inspectors, or to the state inspector, and the findings of the original inspector are approved, the expense incurred as the result of the appeal shall be paid by the owner, and, in case of his refusal to do so, the amount shall be certified to the township board, or village or city council, which shall allow the same and assess it as a special tax upon the property. SEC. 16. In case the owner, or the person in charge of trees, shrubs, vines, or plants, infested with a destructive insect, or a dangerously contagious disease, refuses or neglects to carry out the orders of the state inspector, or of the township, village, and city inspectors, within the period stated in the notice served upon him, the state, township, village, or city inspectors, respectively, shall employ such aid as may be necessary to carry out their orders and recommendations. In case the owner refuses to reimburse them for the expense incurred, it shall be certified to the township board, or village, or city council. who shall allow it, and spread it as a special tax upon the property concerned.

SEC. 17. The state inspector of orchards and nurseries and his deputies, assistants and emploves, shall have authority to enter upon any premises in the state for the purpose of examining the trees, shrubs, plants and vines, for the presence of destructive insects and diseases, and, if any such insects or diseases are found, may, under the provisions of this act, take 
such steps as may be necessary to exterminate them. Town-, Authority of ship, village and city inspectors shall have the same authority township, etc., within the limits of their respectire jurisdiction. No damage No damage shall be awarded for the destruction of any tree, shiub, plant awarded for or fruit, or for injury to the same, if done by the inspectors trees. and their assistants in accordance with the provisions of this act: Provided, It is deemed necessary in order to suppress Proviso. dangerous insects and diseases.

SEc. 18. The township, village and city fruit and tree in-Inspectors, spectors shall be allowed for services nuder this act three dollars for each full day and one dollar fifty cents for each half day, and their per diem and other charges and disbursements hereunder shall be andited by the township board ol: village or city council.

Am. 1911, Act S3.

SEC. 19. Persons, firms or corporations engaged in growing who not reol selling plants commonly glown in aremhomses sha!l not lo quired to take required to take out a license: Provided, They do not grow Proviso. or handle nursery stock, and certificates of inspection are not required under this act for the shipment of greenhouse plants.

SEc. 20. Any person or persons, firm, or corporation, who Misdemeanor, may fail to comply with any of the provisions of this act, who deemed shall be deemed guilty of a misdemennor and shall be punished by a fine of not less than ten dollars and not exceeding one Penalty. hundred dollars, or by imprisonment in the county jail for not less than ten nor more than ninety days or both such fine and imprisomment, in the discretion of the comt, and jurisdic-courts given tion is hereby conferred in these cases upon any justice of the peace, or other competent court, of the township, village, or city, where such trees, shrubs or plants may be, or where such nursery stock or fruit is grown, sold, shipped, disposed of, or delivered, contrary to the provisions of this act. In all security for catses where a complaint is made muler the provisions of any costsmot not. section of this act, by any state, township, village or cits inspector, said complainant shall not be required to furnish security for costs.

SEC. 21. The state inspector of orchards and nurseries state inshall have authority to employ such aid and obtain such appa- inutors 1hat ratus and supplies as may be needed for the proper perform- plies, etc. ance of his duties, and the bills for the same, and for the per Bills, how diem and traveling and other.necessary expenses of the state audited. inspector, his deputies and assistants, shall be andited by the state board of agriculture, and the auditor genel'al shall draw his warrant for the payment of the same from the general fund of the state: Provided, That all moneys collected by the Proviso. state board of agriculture, under this act shall be paid into the state treasury. 
An Act for preventing the manufacture, sale or transportation of adulterated or misbranded Paris greens, lead arsenates, and other insecticides, and also fungicides, and for regulating traffic therein.

[Act 254, P. A. 1913.]

\section{The People of the State of Michigan enact:}

Adulteration unlawful.

Penalty

Uniform rules, etc.

Examination of specimens.

Hearing

Prosecutions.
Section 1. It shall be unlawful for any person to manufacture, sell, offer or expose for sale within the state of Michigan any insecticide, Paris green, lead arsenate, or fungicide which is adulterated or misbranded within the meaning of this act; and any person who shall violate any of the provisions of this act shall be guilty of a misdemeanor and upon conviction thereof shall be fined not to exceed two hundred dollars for the first offense, and upon conviction for each subsequent oflense shall be fined not to exceed three hundred (lollar's, or sentenced to imprisonment in the county jail for a period not exceeding ninety days, or both in the discretion of the court.

SEc. 2. The state board of agriculture shall make uniform rules and regulations for carrying out the provisions of this act, including the collection and examinations of specimens of insecticides, Paris green, lead arsenates, and fungicides manufactured or offered for sale in the state of Michigan.

SEc. 3. The examination of specimens of insecticides, Paris greens, lead arsenates, and fungicides shall be made at the agricultural college by such existing departments as may be directed by the state board of agriculture for the purpose of determining from such examination whether such articles are adulterated or misbranded within the meaning of this act; and if it shall appear from any such examination that any of such specimens are adulterated or misbranded within the meaning of this act, the state board of agriculture shall cause notice thereof to be given to the party from whom such sample was obtained. Any party so notified shall be given an opportunity to be heard, under such rules and regulations as may be prescribed as aforesaid, and if it appears that any of the provisions of this act have been violated by such party, then the state board of agriculture shall at once certify the facts to the attorney general, or prosecuting officel of the county in which the offense is committed, with a copy of the results of the analysis or the examination of such article duly authenticated by the analyst or officer making such examination under the oath of such officer. After judgment of the court, notice shall be given by publication in such manner as may be prescribed by the rules and regulations aforesaid.

SEc. 4. It shall be the duty of the attorney general or other prosecuting officer to whom the state board of agri- 
culture shall report any violation of this act, to cause appropriate proceedings to be commenced and prosecuted in the proper courts of the state of Michigan without delay, for the enforcement of the penalties as in such case herein provided.

SEC. 5. The term "insecticide" as used in this act shall Terms include any substance $0 l^{\circ}$ misture of substances intended to defined. be used for preventing, destroying, repelling or mitigating any insects which may infest vegetation, man or animals, or households, or be present in any environment whatsoever. The term "Paris green" as used in this act shall include the product sold in commerce as Paris green and chemically known as the aceto-arsenite of copper. The term "lead arsenate" as used in this anct shall include the product or prodncts sold in commerce as lead arsenate and consisting themically of products derived from arsenic acid $\left(\mathrm{H}_{3} \mathrm{AsO}_{4}\right)$ by replacing one or more hydrogen atoms by lead. The term "fungicide" as used in this act shall include any substance or mixture of substances intended to be used for preventing, destroying, repelling, or mitigating any and all fungi that may infest vegetation or be present in any environment whatsoever.

SEC. 6. For the purpose of this act an article shall be Adulterated deemed to be adulterated, in case of Paris green:

First, If it does not contain at least fifty percentum of arsenious oxide;

Second, If it contains arsenic in water-soluble forms equivalent to more than three and one-half per centum of arsenious oxide:

Third. If any substance has been mixed and packed with it so to reduce or lower or injuriously affect its quality or strength.

In the case of lead arsenate:

First, If it contains more than fifty percentum of water;

Second, If it contains total arsenic equivalent to less than twelve and one-half per centum arsenic oxide $\left(\mathrm{As}_{2} \mathrm{O}_{5}\right)$;

Third, If it contains arsenic in water-soluble forms equivalent to more than seventy-five one-hundredths percentum of arsenic oxide $\left(\mathrm{As}_{2} \mathrm{O}_{5}\right)$;

Fourth, If any substances have been mixed and packed with it so as to reduce, lower, or injuriously affect its quality or strength: Provided, however, 'That extra water may be added Proviso, to lead arsenate (as described in this paragraph) if the re-water. sulting mixture is labeled lead arsenate and water, the per. centage of extra watel being plainly and correctly stated on the label.

In the case of insecticides or fungicides, other than Paris Insecticinles, green and lead arsenate:

First, If its strength or purity fall below the professed green. standard or quality under which it is sold; 
False branding, defined.

Second, If any substance has been substituted wholly or in part for the article;

Third, If any valuable constituent of the article has been wholly or in part abstracted;

Fourth, If it is intended for use on vegetation and shall. contain any substance $0 r^{*}$ substances which, although preventing, destroying, repelling, or mitigating insects, shall be injurious to such regetation when used as recommended by the manufacturer.

SEc. 7. The term "misbranded" as used herein shall apply to all insecticides, Paris green, lead arsenates, $o r^{*}$ fungicides (1) articles which enter into the composition of insecticides or fungicides, the package or label of which shall bear any statement, design, or device regarding such article or the ingredients or substances contained therein which shall be lalse $01^{\circ}$ misleading in any particular, and to all insecticides, Paris green, lead arsenates, or fungicides which are falsely branded as to the state, teritory, $\mathrm{Or}^{2}$ country in which they are manufactured. For the purpose of this act an article shall be deemed to be misbranded, in the case of insecticides,

Paris greens, lead arsenates and fungicides:

First, If it be an imitation or offered for sale under the name of another article:

Second, If it is labeled or branded so as to deceive or mislead the purchaser, or if the contents of the packages as originally put up shall be removed in whole $o r^{\circ}$ in part and other contents shall have been placed in such packages;

'Third, If in package form, and the contents are stated in lerms of weight and measure, they are not plainly and correctly stated on the ontside of the package; in this connection it is held to be permissible to state the average net weight of the package.

In the case of insecticides (other than Paris green and lead arsenates) and fungicides:

First, If it contains arsenic in any of its combinations or in the elemental form and the total amount of arsenic present (expressed as per centum or metallic arsenic) is not stated on the label;

Second, If it contains arsenic in any of its combinations or in the elemental form and the amount of arsenic in watersoluble forms (expressed as per centum or metallic arsenic) is not stated on the label;

Third, If it does not state plainly upon the label the correct names and percentage amounts of each and every ingrediont of the insecticide or fungicide having insecticidal or fungicidal properties and the total percentage of inert ingredients present.

Guaranty. SEC. S. No dealer shall be prosecuted under the provisions of this act when he can establish a guaranty signed by the wholesaler, jobber, manufacturer, or other party residing in the state of Michigan from whom he purchased such articles, 
to the effect that the same is not adulterated or misbranded within the meaning of this act, designating it. Said guaranty, to afford protection, shall contain the name and address of the party or parties making the sale of such articles to such dealer, and in such case, said party or parties shall be amenable to the prosecutions, fines, and other penalties which would attach in due course to the dealer under this act.

SEc. 9. The word "person" as used in this act, shall be "Person" construed to import both the plural and the singular, as the case demands, and shall include corporations, companies, societies, and associations. When construing and enforcing the provisions of this act, the act, omission, ol fallue of any officer, agent or other peson acting for or emploper hy ally (orporation, company, society or association, within the sonpe of his emplorment or office shall in every case be also deemed to be the act, omission, or failure of such corporation, company, society, or associaton as well as that of the other persoll.

SEc. 10. The necessary expense incurred in carrying out Expense, the provisions of this act, shall be paid by warrant of the how paid. auditor general drawn upon the state treasurer. Such expenses shall be certified to the auditor general by the state board of agriculture, but the total amount to be paid in any one fiscal year shall not exceed five hundred dollars.

Sec. 11 repeals acts 91 and 163 of 1909 and all conllicting acts or parts of aets.

An Act to prevent trespass upon cranberry marshes.

[Act 38, S. L. 1869.]

The People of the State of Michigan enact: \$ 11643. SECTION 1. That if any person shall entel the Penalties for premises of any other person, and take and carry away cranberries or cranberry vines there growing, shall trample or otherwise injure or destroy the cranberry vines growing thereon, without the permission of the owner or occupant of said premises, such person shall be deemed guilty of a misdemeanor, and on conviction thereof, shall be punished by imprisonment in the county jail not less than five days, or by fine not less than fire dollars, and costs of prosecution, or both such fine and imprisonment, in the discretion of the court: and if any of the offenses mentioned in this section shall be Further committed on the first day of the week, $\mathrm{Ol}^{2}$ in disguise, or secretly in the night-time, between sun-setting and sun-rising, on conviction thereof the punishment shall not be less than twenty dollars fine, or imprisonment in the county jail not less than ten days, or both, at discretion of the court. 
Treble damages.

Trespassing, what deemed.

Proviso, notice.

Penalty

When liable in treble damages.

$\$$ 11644. SEC. 2. Any person who shall commit any of the acts of trespass in section one of this act, shall be liable in treble damages, in an action of trespass to be brought in the name of the owner or occupant of the land upon which said trespass may have been committed.

An Act to prevent trespass upon huckleberry and blackberry marshes and to provide a penalty therefor, and to provide for the collection of damages growing out of such trespass.

[Act 261, P. A, 1909.]

\section{The People of the State of Michigan enact:}

SECTrox 1. If any person shall enter the enclosed premises of another person and take and carry away from any huckleber'y marsh or lands growing blackberries, huckleberries or blackberries there growing, or shall trample, break down or otherwise destroy the huckleber'ry or blackber'ry bushes growing thereon, without the permission of the owner or occupant of such premises: Provided, That such owner or occupant shall have previously posted a conspicuous notice in at least three different places upon the premises forbidding any trespass thereon, such person shall be deemed guilty of a misdemeanol, and on conviction thereof, shall be punished by imprisonment in the county jail not less than five days nor more than fifteen days, $0 r^{\circ}$ by a fine of not less than five dollars nor more than twenty-five dollars and the costs of prosecution, or both such fine and imprisonment in the discretion of the court.

SEc. 2. Any person who shall commit any of the acts of trespass mentioned in section one of this act, shall be liable in treble damages in an action of trespass to be brought in the name of the owner or oceupant of the land upon which said trespass may have been committed.

An Act to protect vineyards, orchards and gardens, and to repeal act number one hundred thirty-one, public acts of eighteen hundred sixty-nine, entitled "An act to protect vineyards in the state of Michigan," being section nine thousand one hundred and ninetyfive of Howell's Annotated Statutes.

$$
\text { [.1.t 7\%, T. A. 1895.] }
$$

\section{The People of the State of Michigan enact:}

\$ 11645. SEction 1. That any person who shall entel a

Penalty for entering
vineyard, orchard or garden. rineyard, orchard or garden, without the consent of the owner. and pick, take, carry away, destroy or injure any of the fruits, vegetables or crops therein, $0 l^{\circ}$ in anywise injure or de- 
stroy any bush, tree, rine or plant, shall be guilty of a misdemeanor, and on conviction thereof shall be punished by imprisonment in the county jail not more than three months, or by fine not less than one nor more than one hundred dollars, $\mathrm{or}^{\circ}$ by both such fine and imprisomment, in the discretion of the court.

Am. 1899, Act 61 .

Scc. 2 repeals Act 131 of 1869 .

An Act to prevent the wilful and malicious destruction of fruit, shade or ornamental trees.

[Act 52, S. L. 1S53.]

The People of the State of Michigan enact:

\$11646. SECTION 1. That erery person who shall wilfully wilful and and malicionsly, ol wantomly and withont atuse, out down or malicious indestroy or otherwise injure any fruit tree or trees, or any or shade trees. other tree or trees, not his own, standing or growing for shade or ormament on the land of another, the damage for which said cutting down, destruction or injury to the owner or owncrs of said tree or trees shall amount to the sum of twenty five dollars, shall be punished by imprisonment in the state prison not exceeding five years, or by imprisonment in the county jail not exceeding one year, or by fine not exceeding five hundred dollars, in the discretion of the court.

An Act to prevent the wrongful taking, detaching from the ground, or injuring any fruit tree, shade tree, ornamental shrub, plant, vine, or vegetable.

\section{[Act 174, S. I, 1855.]}

\section{The People of the State of Michigan enact:}

s 11647. SEcrion 1. That any person who shall wrong- Wrongful fully take and ary away from any place, any frut tree. takeng of fruit ornamental tree, shade tree, ornamental shrub, or any plant, punished. vine, bush, or vegetable there growing, standing, or being, with intent to deprive the owner thereof, or who shall without right and with wrongful intent, detach from the ground, or injure any fruit tree, ormamental tree, shade tree, ormamental shrub, or any plant, vine, bush, or vegetable, shall be guilty of a misdemeanor, and on conviction thereof be punished by imprisonment in the county jail not more than six months, 
$01^{\circ}$ by fine not exceeding two hundred and fifty dollars, or by both such fine and imprisonment, in the discretion of the Proviso. court: Provided, That when the damage to the owner does not exceed the sum of twenty-five dollars, the punishment shall be a fine not exceeding one hundred dollars, or imprisonment in the said jail not exceeding three months, or by both such fine and imprisonment, in the discretion of the court.

An Act to prevent fraud and deception in the sale of Michigan grown fresh fruits and vegetables, and to provide penalties for violations of this act.

[Act 207, P. A. 1913.]

\section{The People of the State of Michigan enact:}

"Closed package", how construed.

How marked. SEC. 2. Every person who, by himself or by his agent $01^{\circ}$ employe, packs or repacks fresh fruits or vegetables in closed packages intended for sale in the open market, shall cause the same to be marked in a plain and indelible manner, as follows :

First, With his full name and address, including the name of the state where such fresh fruits and vegetables are packed, before such fresh fruits or vegetables are removed from the yremises of the packer or dealer;

Second, The name and address of such packer or dealer shall be printed or stamped on said closed packages in letters not less than one-quarter inch in height.

Sale, etc., when unlawful.

Śluc. 3. No person shall sell or offer, expose or have in his possession for sale, in the open market, any fresh fruits or regetables packed in a closed package and intended for sale, muless such package is marked as is required by this act.

when marked SEc. 4. No person shall sell or offer, expose or have in his "fancy", etc. possession for sale, any fresh fruits or vegetables packed in a closed $o r^{2}$ open package, upon which package is marked any designation which represents such fruit as "No. 1," "Finest," "Best," "Extra Good," "Fancy," "Selected," "Prime," "Standard," or other superior grade or quality, unless such fruit $\mathrm{ol}^{*}$ regetables consist of well grown specimens, sound, of 
nearly uniform size, normal shape, good color, for the variety, and not less than ninety per cent free flom injurious $0 r^{2}$ disfiguring bruises, diseases, insect injuries or other defects, natural deterioration and decay in transit or storage excepted.

SEC. 5. No person shall sell or offer, expose or have in his False represenpossession for sale, any fresh fruits or vegetables packed in any package in which the faced or shown surface gives a false representation of the contents of such package, and it shall be considered a false representation when more than twenty per. cent of such fresh fruits or regetables are substantially smaller in size than $\mathrm{or}^{\circ}$ inferior in grade to, or different in variety from, the faced or shown surface of such package, natural deterioration and decay in transit or storage excepted.

SEC. 6. Every person who, by himself, his agent o1 em-Misdemeanor, ploye, knowingly violates any of the provisions of this act penalty. shall, for each such offense, be deemed guilty of a misclemeanor, and upon conviction thereof shall be punished by a fine not exceeding ten dollars, or by imprisomment in the county jail for a period not exceeding thirty days, or by both such fine and imprisonment in the discretion of the conrt.

An Act to regulate the packing for shipment and sale of table grapes, and providing penalties for violation thereof.

$$
\text { [Act } 107, \text { P. A. 1913.] }
$$

\section{The People of the State of Michigan enact:}

Section 1. No grapes that are not ripe, $0 r^{*}$ are the fruit of Unripe, etc., unhealthy vines, ol a $l^{\circ}$ for any leason unlealthy or in a state grapes, ship of decay shall be packed for shipment by any grower, packer or shipper in any package or basket of less than sixteen pounds capacity.

SEC. 2. Any person or persons found guilty of violating Penalty for any of the provisions of this act, in any court of competent jurisdiction, shall be deemed guilty of a misdemeanor and shall be punished by a fine of not less than ten dollars nor more than one hundred dollars, or by imprisonment in the county jail for not less than ten days nor more than ninety days, $\mathrm{or}^{\circ}$ by both such fine and imprisonment in the discretion of the coult.

SEc. 3. It shall be the duty of the state dairy and food Enforcement. commissioner, his deputies and assistants, to enforce the provisions of this act. 
An Act to authorize and regulate a county agricultural department.

$$
\text { [Act 67, P. A. 1913.] }
$$

\section{The People of the State of Michigan enact:}

Appropriations.

Proviso, limit.

Farm commissioner.

term, salary

Farm develop ment fund.

Salary, how paid.

Qualifications. salaries are paid.

Section 1. The boards of supervisors of the several counties of this state are hereby authorized to appropriate from funds of their respective counties, or to assess and cause to be spread upon the taxable property of their respective counties, a sufficient sum of money to carry out the purposes of this act: Provided, however, That there shall not be so appropriated, raised or assessed in any county in any one year more than fifty cents on each one thousand dollars or major portion thereof of the assessed valuation of the real and personal property of such county, but in no case to exceed two thousand dollars, in addition to the salary mentioned in this act.

SEc. 2. Each of said boards of supervisors so making such appropriation or assessment, shall also elect one qualified person for each county, respectively, to be known as farm commissioner, who shall hold his office for two years and shall receive such annual salary as said board of supervisors shall determine, not exceeding two thousand dollars.

SEc. 3. The fund so appropriated shall be known as the farm development fund, and the same may be used to enable said commissioner to defray his actual expenses, aside from salary, and carry out the purposes of this act.

Sec. 4. The salary of such commissioner shall be paid out of the general fund of such county, and as other county

SEC 5. Such commissioner shall be a person not less than twenty-five years of age, an experienced practical man who, in the opinion of said board, is rersed in all matters pertaining to farming pursuits, the growing of agricultural products and fruits suitable in such county, and one who is rersed in the knowledge of soil fertility, rotation of crops, fertilizers and fertilizing, and possessing a knowledge of the kind of crops best adapted to the rarious soils and con. ditions of such county.

Oath of office. SEc. 6. Such commissioner shall, before entering upon the duties of his office, execute the constitutional oath of office and file same with the county clerk of such county; and shall also before entering upon such duties execute and enter into a bond in a sum to be fixed by said board of supervisors, not less than one thousand dollars nor to exceed double the sum appropriated in the then current year, said bond to be signed by at least two sureties and approved by the county treasurer of the county, conditioned for the faithful performance of his duties and the accounting of all funds and moneys, material and apparatus coming into 
his hands; which bond shall run to the board of supervisors of such county and shall be filed in the office of the county clerk thereof, and action may be brought thereon for violations of its conditions and provisions, the same as on other county officers' bonds running to said board.

SEc. 7. The fund created by this act shall be raised and Fund, how collected as are other taxes for county expenses, and paid raised, ete. over to the county treasurer, and by him kept separate from all other funds, and to be paid out only on the order of said farm commissioner or transferred to the general fund of such county as hereinafter specified.

SEc. 8. Such commissioner shall keep an accurate account Expenditures, of all of the expenditures by him made from such fund and etcount of. of the orders drawn thereon, and he shall make annual report of all such expenditures and orders drawn, and of his doings and actions in full to the board of supervisors of such county at each annual October meeting thereof.

SEC. 9. The duties of such commissioner in general shall Duties of be as follows:

a. To be of erery material benefit and assistance to the farming and fruit interests of his county;

b. To render advice and instruction to the people of the county who need. help most, to make for successful cultivation and cropping of the soil for all products grown therefrom;

c. To contract with farmers and fruit growers through out the county for demonstration and experimental purposes, for acreage of ground and orchards or small fruits, to the end that each farmer or fruit grower so contracted with will fertilize, fit for crops, plant and sow to crops and care for and harvest the same in accordance with the instruction and direction of such commissioner, but without compensation; such farmer to have the crop grown thereon and to keep such records and data concerning the same, as to the kind of seed and fertilizer used, cultivation, rain fall on same, harvest, care and yield of crop and other informatiou as such commissioner shall require;

d. Such commissioner to so manage and keep records of each tract that each mar be such a demonstration and experiment station in itself as to tend to bettering future conditions ;

e. To instruct as far as possible the inhabitants as to important farm questions relating to soil fertility, crop rotation, fertilizers (crop and commercial), kinds of crops best adapted to rarious soils, and in every way to raise and improve the standard of farming and fruit growing;

f. To work in conjunction with the Michigan agricultural college $0 r^{\circ}$ any governmental or state aid that may be secured by federal or state appropriations for similar purposes:

g. To stimulate interest for more scientific farming and 
fruit growing, and in every reasonable and practical way raise the standard of farming and fruit growing in such county.

office. SEC. 10. Said commissioner shall keep an office in such county, and there keep on file and for public examination in systematic form, records, data and results of the various experiments and demonstrations in such a way as to be of the greatest benefit to the public, and turn over to his successor in office all the records, files and documents, fixtures, apparatus and material of his said office which shall belong to the county.

May contract with farmers, etc.

Proviso.

Oftice fixtures, etc., may purchase.

Proviso.

Supervisors may discontinue office.

Proviso

Further proviso, referendum.

Funds, where applicable.

Proviso
SEC. 11. Such commissioner may enter into contracts with farmers and fruit growers in his name of office, and sue them for violations thereof in his name of office, and may employ such assistants as he deems necessary to carry on the work outlined by this act to the best advantage: Provided, however, That said commissioner shall devote substantially his whole time to said work, and shall not expend portions of swch development fund for other assistants, excent when the same are necessary to carry out the purposes of this act to the best adrantage and benefit to the people.

SEC. 12. Such commissioner is authorized to purchase such reasonable office fixtures and supplies and record books as are necessary to carry out the provisions of this act, and is authorized to purchase such reasonable supply of apparatus and chemicals and material as is necessary for him to test soils, fertilizers, spraying materials and seeds, and carry on experiments; but he shall make no charge for such testing nor for any other services performed under this act, and he shall receive no other or further compensation or fees than such as are prescribed by this act: Provided, however, That if such commissioner can procure adequate tests of above materials, soils, etc., at the agricultural college of the state, it shall be the intent of this act that he shall so do, and only purchase material for or hire such testo made as are necessary for adequate and efficient service in the work of his said office.

SEC. 13. The board of supervisors of each county having appropriated or raised funds under this act may discontinue the office, and discontinue the raising of further funds thereunder by a resolution of such board adopted by a majority of the members thereof: Provided, however, That such action shall not terminate the office or salary of any commissioner elected thereunder until the expiration of his term of office as provided herein: Provided further, That the said office shall not be terminated except by a referendum vote the same as is provided in section fifteen for its adoption.

SEC. 14. No funds appropriated or raised under this act shall be used for contribution to agricultural societies or any other purpose than that prescribed in this act: Provided, however, That if such office and work should be discontinued 
by resolution of the boald of supervisors, then in that case all moneys remaining in such development fund shall there. upon be by such county treasurer transferred to the general fund of such county: And provided further, 'That funds Further raised under the act may, by resolution of the board of super- proviso. visors or by order of said farm commissioner, be appropriated or used to comply with and in co-operation with any state or govermmental requirements for agricultural development, demonstration or experimental work in each county respec tively.

EEC. 15. The provisions of this act shall not apply in any Referendum. comnty of this state until the question of adopting the same shall have been submitted to the qualified electors thereof. Such question may be submitted either by resolution of the board of supervisor's or upon petition, signed by not less than five per cent of the qualified electors resident in such county, addressed to said board. Upon receipt of such petition it shall be the duty of the board of supervisors to submit the question at the first general election held after the meeting of the board at which the petition is presented, or at a special election called for that purpose. Ballots for the submission Ballots. of such question shall be prepared and distributed by the same officers as are required by law to prepare and distribute ballots for county elections, and the canvass and return of the vote thereon shall be the same as is provided by law for the canvass and return of the vote upon county officers. If upon the canvass of the votes upon such question it shall appear that a majority of the electors roting thereon, are in favor of the adoption of the provisions of this act in their respective counties, then this act shall be in full force and effect in such county and not otherwise. 




LIBRARY OF CONGRESS

00209731307 